\title{
Cell volume to cell carbon conversion factors for a bacterivorous Monas sp. enriched from seawater
}

\author{
Knut Yngve Børsheim \& Gunnar Bratbak
}

Department of Microbiology and Plant Physiology, University of Bergen, Allegt. 70, N-5000 Bergen, Norway

\begin{abstract}
A bacterivorous Monas sp. was enriched from seawater. Particulate carbon of the enrichment cultures was measured together with flagellate and bacterial number and volume. The volume of flagellates was measured on living and on preserved cells using several different preservation and microscopy procedures and Coulter Counter. The specific carbon content of the living flagellates was found to be $100 \mathrm{fgC} \mathrm{mm}^{-3}$. For preserved cells measured in the epifluorescence

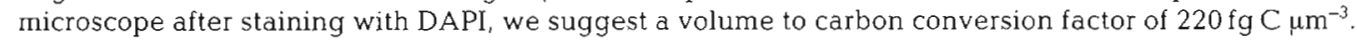

\section{INTRODUCTION}

Heterotrophic flagellates are in general considered the most important group of bacterivores in marine planktonic ecosystems, in terms of both number and of bacterivorous activity (Pomeroy \& Johannes 1968, Sorokin 1977, Haas \& Webb 1979, Fenchel 1982a, b, c, $d$, Sherr \& Sherr 1983). Increasing effort is therefore being made to estimate the abundance and activity of the members of this group (Wright \& Coffin 1984, Andersen \& Fenchel 1985, McManus \& Fuhrman 1986, Wikner et al. 1986).

In oceanographic investigations of the microbial loop' (Azam et al. 1983), the biomass of flagellates is usually estimated by quantitative and qualitative microscopy of preserved samples. After staining with fluorescent dyes, the number of organisms that can be identified as heterotrophs are counted, and sizes of the organisms may be measured. In interdisciplinary studies of the food web, where comparisons among different groups of organisms are necessary, interpretation of measurements from microscopy often need conversion factors from size to biomass.

We have not been able to locate in the literature any experimentally determined volume to carbon conversion factors for naked heterotrophic flagellates. For these organisms conversion of size data to biomass estimates has previously been based on general assumptions about cell composition (Beers et al. 1975), or on empirical regression equations derived from data on various phytoplankton species (e.g. Mullin et al. 1966, Strathmann 1967, Eppley et al. 1970).
Here we report results from carbon and nitrogen analysis of bacterivorous flagellates which are compared to Coulter Counter volume measurements and to size measurements obtained using different quantitative microscopy methods. We used an enrichment culture similar to the enrichments used by Sherr \& Sherr (1983) and Andersen \& Fenchel (1985). Such cultures are also suitable to estimate gross growth efficiency of bacterivorous flagellates.

\section{MATERIALS AND METHODS}

Seawater samples were collected from Raunefjorden outside Bergen on the west coast of Norway $\left(60^{\circ} 10^{\prime} \mathrm{N}\right.$, $\left.5^{\circ} 12^{\prime} \mathrm{E}\right)$. For enrichment of bacterivorous flagellates, Whatman GF/F-filtered seawater received additions of glucose, nitrate and phosphate to final concentrations of $0.08,0.3$, and $0.02 \mathrm{mmole}^{-1}$ respectively. Sterile 21 round flasks were filled with medium, inoculated with $10 \mathrm{ml}$ of unfiltered sample, and incubated at $16^{\circ} \mathrm{C}$ in the dark. Sterile air bubbling was applied for stirring and aeration. In this enrichment culture, glucose will be the first growth-limiting substrate (Bratbak 1985).

Particulate organic carbon was measured in a Carlo Erba elemental analyzer mod-1106, after collecting the particles on ignited $\left(450^{\circ} \mathrm{C}\right)$ Whatman $\mathrm{GF} / \mathrm{F}$ filters, applying a suction of approximately $100 \mathrm{~mm} \mathrm{Hg} \mathrm{du-}$ ring filtration. The filters were not washed after filtration; a series of different volumes were filtered for analysis, and background was estimated by extrapolating to zero volume. 


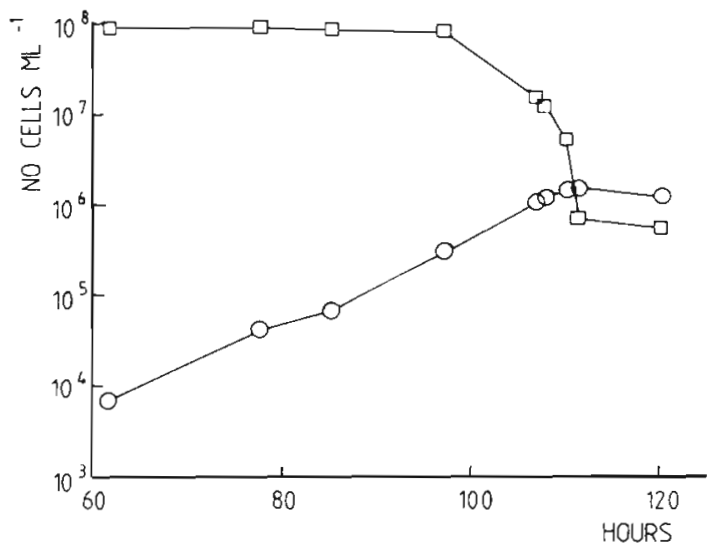

Fig. 1. Time course of bacterial and flagellate growth in an enrichment culture from seawater. $(\square)$ Bacteria; (O) flagellates

Samples were fixed with $25 \%$ glutardialdehyde (Merck, Electron Microscope grade), with $30 \%$ borax buffered formaldehyde (Sherr \& Sherr 1983), with saturated $\mathrm{HgCl}_{2}$, or with Lugol's Blue $\left(20 \mathrm{~g} \mathrm{KI}\right.$ and $10 \mathrm{~g} \mathrm{I}_{2}$ dissolved in $100 \mathrm{ml} 0.2 \mu \mathrm{m}$ filtered distilled water and $20 \mathrm{ml}$ of glacial acetic acid). The final concentrations of each preservative tested is reported in 'Results'.

Number and volume of flagellates in both untreated and in preserved samples were determined in a Coulter Counter Model ZM (Coulter Electronics Ltd, England). The enrichment medium (filtered through $0.2 \mu \mathrm{m}$ poresize Millipore filters) was used for diluting the samples for counting.

For fluorescence microscopy preserved samples were filtered onto Irgalan Black stained $0.2 \mu \mathrm{m}$ Nuclepore filters, stained for 10 min with DAPI (Porter \& Feig 1980), and mounted in paraffin. The Lugol stained samples were bleached with 2 drops of $0.25 \mathrm{M} \mathrm{Na}_{2} \mathrm{~S}_{2} \mathrm{O}_{3}$ before staining with DAPI (Pomroy 1984). The sizes of bacteria and flagellates were measured with an eyepiece graticule (New Porton G 12, Graticules Ltd, England) as described by Bratbak (1985). The size of the flagellates were also measured in a phase contrast microscope using a magnification of $1000 \times$ and an eyepiece graticule with a linear scale divided into $1 \mu \mathrm{m}$. The samples were in this case concentrated by sedimentation in Utermöhl chambers. Cell volumes of the bacteria were calculated as $W^{2}(L-W / 3) \pi / 4$, and cell volumes of the flagellates were calculated as $W^{2} \mathrm{~L}$ $\pi / 6$ where $L$ and $W$ are the measured length and width of the cells.

\section{RESULTS AND DISCUSSION}

A typical development of the enrichment cultures is shown in Fig. 1. The bacteria entered a stationary phase at $8.8 \times 10^{7}$ cells $\mathrm{ml}^{-1}$. The flagellates reached detectable levels approximately $3 \mathrm{~d}$ after the start of the experiment, and grew exponentially with a specific growth rate based on cell numbers of $0.11 \mathrm{~h}^{-1}$ until they reached a stationary phase, where flagellate number exceeded the bacterial number.

The gross growth efficiency of flagellates grazing bacteria was $23 \%$ in our experiment as calculated from carbon estimates of bacteria and flagellates (see below). Sherr et al. (1982) found the growth efficiency of Monas sp. from Lake Kinneret to be 23.7 to $48.7 \%$ when grown on different bacteria. Fenchel (1982b) found the gross growth efficiency of Ochromonas sp. and Pleuromonas jaculans to be 34 and $43 \%$ respectively.

When the bacteria had reached the stationary phase, samples were taken to establish a volume to carbon conversion factor for the bacteria. Based on results from 3 different enrichment cultures containing rodshaped bacteria with a mean volume between 0.4 and $0.6 \mu \mathrm{m}^{3}$ after preservation with $2.5 \%$ glutardialdehyde (final concentration), the conversion factor was found

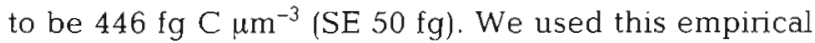
value in our subsequent calculation of bacterial biomasses in the cultures when flagellates dominated. This value is $80 \%$ of the conversion factor suggested by Bratbak (1985), but higher than other published values (Nagata 1986). The mean nitrogen content of the same bacteria (glucose limited) was $108 \mathrm{fg} \mathrm{N} \mathrm{Nm}^{-3}$ (SE $7 \mathrm{fg}, \mathrm{n}=3$ ).

Table 1 shows the results from an enrichment culture of Monas sp. analyzed in the early stationary growth phase of the flagellate. The amount of particulate detritus present was judged to be negligible after careful examination of the samples with phase contrast microscopy. From the results in Table 1 the specific carbon content of the living flagellates is calculated to

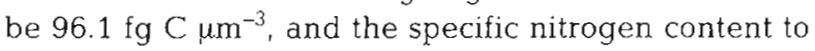
be $21 \mathrm{fg} \mathrm{N} \mu \mathrm{m}^{-3}$.

Table 1. Monas sp. Composition of an enrichment culture

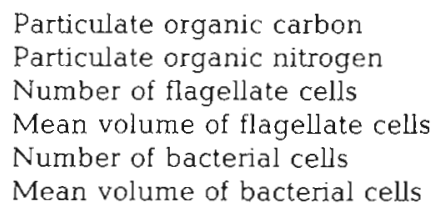

Particulate organic carbon

Particulate organic nitrogen

Number of flagellate cells

Mean volume of flagellate cells

Number of bacterial cells

Mean volume of bacterial cells

$\begin{array}{ll}668.8 & \mu \mathrm{g} \mathrm{C} \mathrm{^{-1 }} \\ 149.8 & \mu \mathrm{g} \mathrm{N} \mathrm{I} \mathrm{I}^{-1} \\ 4.19 \times 10^{8} & \text { cells l}^{-1} \\ 15.09 & \mu \mathrm{m}^{3} \\ 1.54 \times 10^{8} & \text { cells I I }^{-1} \\ 0.411 & \mu \mathrm{m}^{3}\end{array}$

$(\mathrm{SE}=1.4 \%)$

$(\mathrm{SE}=6.0 \%)$

$(\mathrm{SE}=3.5 \%)$

( $\mathrm{SE}=0.8 \%$ )

$(\mathrm{SE}=8.0 \%)$

( $S E=12 \%$ ) 
Table 2. Monas sp. Volume estimates after preservation as percent of live volume. The live volume as measured with the Coulter Counter was $15.09 \mu \mathrm{m}^{3}$

\begin{tabular}{|c|c|c|c|c|c|}
\hline \multirow[t]{2}{*}{ Preservative } & \multirow{2}{*}{$\begin{array}{c}\mathrm{Ml} \text { of preservative added } \\
\text { to } 50 \mathrm{ml} \text { sample }\end{array}$} & \multicolumn{4}{|c|}{ Method } \\
\hline & & $\begin{array}{c}\text { Coulter } \\
\text { Counter } 1\end{array}$ & $\begin{array}{c}\text { Coulter } \\
\text { Counter } 2\end{array}$ & DAPI & Phase contrast \\
\hline \multirow[t]{2}{*}{ Glutardialdehyde } & 1 & 46.5 & 44.4 & 43.9 & 58.5 \\
\hline & 5 & 50.3 & 51.2 & 65.7 & 49.8 \\
\hline \multirow[t]{2}{*}{ Formaldehyde } & 1 & 60.0 & 41.0 & 50.2 & 57.3 \\
\hline & 5 & 72.8 & 46.6 & 56.0 & 76.2 \\
\hline \multirow[t]{2}{*}{$\mathrm{HgCl}_{2}$ (sat.) } & 1 & 49.6 & 45.9 & 33.7 & 86.2 \\
\hline & 5 & 80.9 & 73.6 & 31.7 & 114.6 \\
\hline \multirow[t]{2}{*}{ Lugol } & 0.5 & 42.9 & 41.3 & 30.4 & 65.3 \\
\hline & 2.5 & 43.2 & 42.9 & ND & 50.0 \\
\hline
\end{tabular}

When measured biovolumes are converted to carbon, it has sometimes been assumed that the density of the cell is equal to unity, that dry weight is $20 \%$ of wet weight, and that carbon is $40 \%$ of dry weight (Beers et al. 1975). This leads to a conversion factor of $80 \mathrm{fg} \mathrm{C}$ $\mathrm{\mu m}^{-3}$, which is $83 \%$ of the value we have measured for living cells of Monas sp.

The empirical equations published by Strathmann (1967) are often referred to when conversion of volumes to carbon is needed (Smayda 1978). He found that vacuole volume influenced the specific carbon content of the cells, whereas plasma volume had a reasonably constant carbon content of $110 \mathrm{fg} \mathrm{C} \mathrm{mm}^{-3}$ $( \pm 50 \%)$. We must assume that Strathmann did not fix his cells since he did not mention preservation in his report. If we use his equation to calculate the carbon content of the Monas sp. we investigated, the resulting

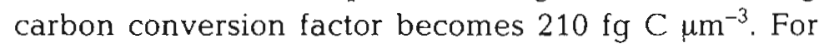
living cells of naked flagellates this seems to be too high when compared to our results, whereas our fixa-

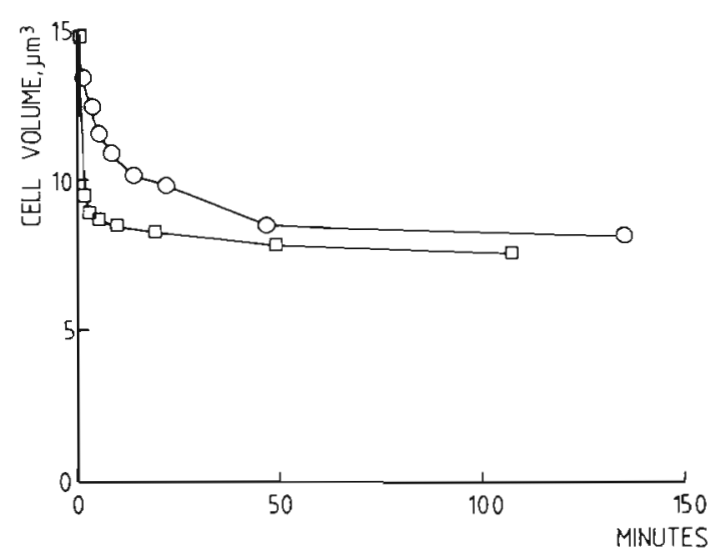

Fig. 2. Monas sp. Time course of the decrease in volume after preservation with glutardialdehyde. (ㅁ) $2.5 \%$ glutardialdehyde; (0) $0.5 \%$ tion experiments have shown that a factor in this size range may be appropriate for preserved naked flagellates (see below). However, values obtained for species with rigid cell walls should not be applied to naked flagellates. Sicko-Goad et al. (1977) showed that cell structure strongly influences cell carbon content, and like Strathmann (1967) they advised that 'empty' vacuole volume should be subtracted when cell volume is calculated for biomass estimation. The 'empty' vacuole content of the naked flagellates they investigated constituted only $3 \%$ of the cell volume, so vacuole volume of naked flagellates will probably be negligible in most cases.

The effect of different commonly used preservation procedures on flagellate number and volume was studied using the Coulter Counter. Preservation did not influence cell number significantly (95\% level) for any of the preservation methods. However, both preservative and concentration of preservative used influenced the mean cell volume (Table 2). The differences between the preservation methods, when compared to the mean and the variance of all methods, were generally small. Excepted from this is the high concentration of $\mathrm{HgCl}_{2}$ which caused the least shrinkage among the procedures we tested. After 2 wk of storage the volume of these cells was $74 \%$ of the live volume (Table 2 ). This value is significantly different from the mean of the other methods (95\% level). This observation supports the recommendation of $\mathrm{HgCl}_{2}$ as preservative by Pace \& Orcutt (1981). If we leave out this highest value, the mean of the others is $45 \%$ (SD $3.6 \%, n=7$ ) of the live volume.

As shown for glutardialdehyde (Fig. 1) the higher concentrations initially caused a more rapid shrinkage than the lower concentrations. After $2 \mathrm{wk}$, however, the lower concentrations of the preservatives generally had caused more shrinkage than the higher concen- 
trations (Table 2). Between 56 and 100\% (average $85 \%$ ) of the change in volume took place within $2 \mathrm{~h}$ for all preservatives.

Since the Coulter Counter cannot replace the use of quantitative microscopy in field studies we compared the volumes measured with the Coulter Counter to the volumes obtained using epifluorescence and phase contrast microscopy. The microscope techniques did not always agree with the Coulter Counter results. Most striking is the small size estimate obtained when $\mathrm{HgCl}_{2}$ fixed cells were measured after staining with DAPI. In phase contrast microscopy, however, these cells appeared larger than the Coulter Counter volume. Using DAPI, the average apparent volume after preservation was $44 \%$ (SD $11.9 \%, \mathrm{n}=8$ ) of live volume. None of the treatments gave size estimates significantly different from the others $(95 \%$ level). The variability of the size measurements done with phase contrast microscopy was larger than when using DAPI. Phase contrast were more in agreement with Coulter Counter measurements, but gave a slightly higher mean. If the average apparent volume obtained using phase contrast microscopy is calculated in the same way as for the Coulter Counter results, leaving out the high concentration of $\mathrm{HgCl}_{2}$, the mean is $63.3 \%$ (SD $13.6 \%, \mathrm{n}=7$ ) of live volume; and if all values are included, the mean is $70 \%($ SD $22 \%, n=8)$.

The suitability of a preservation procedure may not only be judged by its ability to preserve the number and volume of the organisms in question. It should also preserve various taxonomic important features such as shape, pigmentation, flagella etc. It may therefore be important to note that the visibility of the flagella was seriously affected by the various preservation and microscopic procedures we used. The flagellae were best visible in the preparations fixed with $\mathrm{HgCl}_{2}$. Glutardialdehyde gave excellent microscope preparations after staining with DAPI, but flagellae were less visible than when cells were preserved with $\mathrm{HgCl}_{2}$ and stained with DAPI. Lugol fixed cells stained with DAPI were very pale and difficult to measure, and the flagellae were not visible at all. However, when observed in phase contrast the Lugol fixed cells were easily recognized and the flagellae were visible.

Fenchel (1982b) reported carbon content of formaldehyde fixed cells of Ochromonas sp. and Pleuromonas jaculans, which contained 180 and $300 \mathrm{fg}$ $\mathrm{C} \mu \mathrm{m}^{-3}$ respectively. The values are in general agreement with our results, but also show that species differences may be of importance. For cells with a similar cell structure as Monas sp., we suggest a conversion

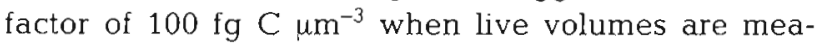
sured. When sizes are measured on preserved cells in the epifluorescence microscope after staining with

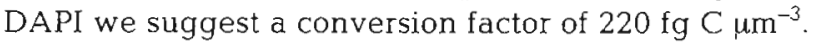

\section{LITERATURE CITED}

Andersen, P., Fenchel, T. (1985). Bacterivory by microheterotrophic flagellates in seawater samples. Limnol. Oceanogr. 30: 198-202

Azam, F, Fenchel, T., Field, J. G., Gray, J. S., Meyer-Rejl, L. A., Thingstad, T. F. (1983). The ecological role of watercolumn microbes in the sea. Mar. Ecol. Prog. Ser. 10: 257-263

Beers, J. R., Reid, F. M. H., Stewart, G. L. (1975). Microplankton of the North Pacific Central Gyre. Population structure and abundance, June 1973. Int. Rev. ges. Hydrobiol. 60: $607-638$

Bratbak, G. (1985). Bacterial biovolume and biomass estimations. Appl. environ. Microbiol. 49: 1488-1493

Eppley, R. W., Reid, F. M. H., Strickland, J. D. H. (1970). The ecology of plankton off La Jolla, California, in the period April to September 1967. Estimates of phytoplankton crop size, growth rate and primary production. Bull. Scripps Inst. Oceanogr. 17: 33-42

Fenchel, T. (1982a). Ecology of heterotrophic microflagellates. I. Some important forms. Mar. Ecol. Prog. Ser. 8: $211-223$

Fenchel, T, (1982b). Ecology of heterotrophic microflagellates. II. Bioenergetics and growth. Mar. Ecol. Prog. Ser. 8: 225-231

Fenchel, T. (1982c). Ecology of heterotrophic microflagellates. III. Adaptations to heterogeneous environments. Mar. Ecol. Prog. Ser. 9: 25-33

Fenchel, T. (1982d). Ecology of heterotrophic microflagellates. IV. Quantitative occurrence and importance as bacterial consumers. Mar. Ecol. Prog. Ser. 9: 35-41

Haas, L. W., Webb, K. L. (1979). Nutritional mode of several non-pigmented microflagellates from the River York Estuary, Virginia. J. exp. mar. Biol. Ecol. 39: 125-134

McManus, G. B., Fuhrman, J. A. (1986). Bacterivory in seawater studied with the use of inert fluorescent particles. Limnol. Oceanogr. 31:420-426

Mullin, M. M., Sloan, P. R., Eppley, R. W. (1966). Relationship between carbon content, cell volume, and area in phytoplankton. Limnol. Oceanogr. 11: 307-311

Nagata, T. (1986). Carbon and nitrogen content of natural planktonic bacteria. Appl. environ. Microbiol. 52: 28-32

Pace, M. L., Orcutt, J. D. (1981). The relative importance of protozoans, rotifers, and crustaceans in a freshwater zooplankton community. Limnol. Oceanogr. 26: 822-830

Porter, K., Feig, Y. S. (1980). The use of DAPI for identifying and counting aquatic microflora. Limnol. Oceanogr. 25: 943-948

Pomeroy, L. R., Johannes, R. E. (1968). Occurrence and respiration of ultraplankton in the upper 500 meters of the ocean. Deep Sea Res. 15: 381-391

Pomroy, A. J. (1984). Direct counting of bacteria preserved with Lugol Iodine solution. Appl. environ. Microbiol. 47 1191-1192

Sherr, B. F., Sherr, E. B., Berman, T. (1982). Grazing, growth, and ammonium excretion rates of a heterotrophic microflagellate fed with four species of bacteria. Appl. environ Microbiol. 45: 1196-1201

Shers, B. F., Sherr, E. B. (1983). Enumeration of heterotrophic microzooplankton by fluorescence microscopy. Estuar. coast. Shelf Sci. 16: 1-7

Sicko-Goad, L., Stoermer, E. F., Ladewski, B. G. (1977). A morphometric method for correcting phytoplankton cell volume estimates. Protoplasma 93: 147-163

Smayda, T J. (1978). From phytoplankton to biomass. In: 
Sournia, A. (ed.) UNESCO Phytoplankton Manual. UNESCO, Paris, p. 273-279

Sorokin, Y. I. (1977). The heterotrophic phase of plankton succession in the Japan Sea. Mar. Biol. 41: 107-117

Strathmann, R. R. (1967). Estimating the organic carbon content of phytoplankton from cell volume or plasma volume. Limnol. Oceanogr. 12: 411-418
Wikner, J., Andersen, A., Normark, S., Hagström, А. (1986). Use of genetically marked minicells as a probe in measurement of predation on bacteria in aquatic environments. Appl. environ. Microbiol. 52: 4-8

Wright, R. T., Coffin, R. B. (1984). Measuring microzooplankton grazing on marine bacteria by its impact on bacterial production. Microb. Ecol. 10: 137-149

This article was presented by Professor J. Gray; it was accepted for printing on December 30, 1986 